\title{
HIDDEN SPINAL DYSRAPHISM IN THE STRUCTURE OF OSTEONEURAL SPINE ANOMALIES IN CHILDREN
}

\author{
*Madzhidova Y.N., Ergasheva N.N., Ergasheva N.N. \\ Tashkent Pediatric Medical Institute, Tashkent, Uzbekistan
}

\begin{abstract}
Despite the long-term study of the problem of spinal dysraphism, its relevance is associated with a high frequency of children born with this disease and long-term effects that have medical-social value. In verified materials there are 144 sick children with osteoneural myelopathy assessed the frequency and characteristics of existing neurological disorders in hidden spinal dysraphism (HSD). Found that a combination of high HSD with urogenital and anorectal anomalies contribute aggravation of their flow.
\end{abstract}

Key words: spinal dysraphism, osteoneural myelopathy, children.

Spinal dysraphism - a collective term that combines a large group of malformations of the spinal cord, spine, with hidden or overt clinicalneurological manifestations and with underlying functions of the musculoskeletal system, pelvic organs and other systems with a common site of injury in the lumbosacral spine $[1,6]$.

Currently, the term "spinal dysraphism" combines various disorders of the spinal cord and spinal column:

- Spina bifida occulta - invisible cleft spine;

- Spina bifida cystica uverta - open spina bifida with the formation of cystic spinal hernia;
- Rhachischiasis posterior (totalis et partialis) - splitting of the spine and soft tissue reattachment to the spinal cord, which occur throughout the backbone or only in some of its parts.

Hidden cleft spine are usually localized in the lumbar - sacral region and usually does not manifest clinically $[2,3]$. Often they are a random "find" X-ray examination of the spine. Skin in the cleft of the vertebral arch is not changed, but can be marked spots, subcutaneous lipomas (lipoma), fistulous passages (dermal sinuses). Anatomical entity of hidden spina bifida is an incomplete vertebral arch overgrown.

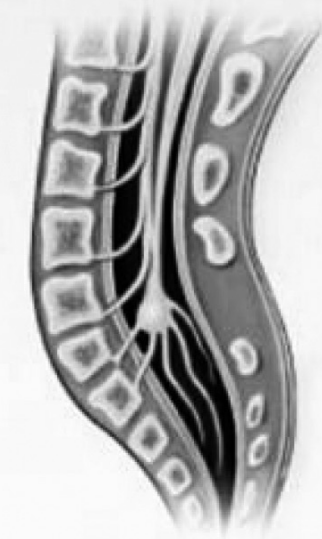

Spina bifida occulta

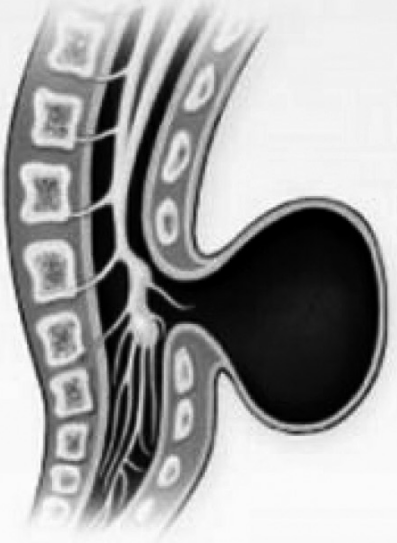

Meningocele

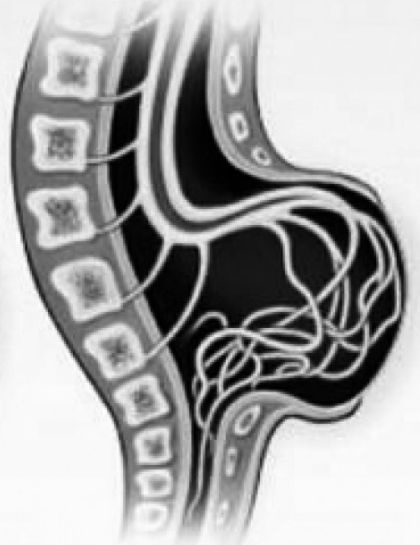

Myelomeningocele

Fig.1. Types of spinal dysraphism

According to A.D. Speranskii, published in 1925 in "The Origin of spina bifida occulta in the sacral region of the human spinal column " argued that the incomplete closure of the sacral arches found in $70 \%$ of people and is the norm. Only subsequent anatomical studies and data currently available diagnostic methods (computed tomography, nuclear magnetic imaging) have revealed concomitant changes in places bifida defect that lead to bedwetting, pain in the lumbosacral region, incorrect posture, less muscle weakness feet, foot deformities, sensitive and

*e-mail: madjidova1@yandex.ru 
trophic disturbances. It is these cases spina bifida occulta require surgical care [3,7]. Latent form of spina bifida often asymptomatic, but if it can be observed not as clear as in the symptoms of spinal hernias and are usually not associated with a specific form of defeat. If it can be seen as symptoms of loss and symptoms of irritation of the nervous system in the form of lumbosacral pain, hyperesthesia, paresthesias in the lower extremities. All manifestations of HSD can be divided into: skin, bone, orthopedic, neurological, disorders of pelvic organs of varying severity. Bone manifestations of HSD are diverse: anomalies and vertebral arches - defects, spina, abnormal development, expansion of the spinal canal, developmental abnormalities of the sacrum - agenesis, dysgenesis, deviation. For orthopedic disorders include: leg deformities, asymmetry of legs and feet, asymmetry of the buttocks, changing gait, posture disorders - scoliosis, kyphosis, lordosis. Pelvic disorders: neurogenic bladder, urinary tract infections, urinary incontinence. Hidden vertebral cleft (spina bifida occulta), as well as the splitting of the vertebral bodies (spina bifida anterior), reveal mainly using X-ray studies. Diagnosis of HSD is prima- rily dependent on the alertness of pediatricians to this pathology. Thus, the presence of a child skin stigmata in the lumbosacral region, the appearance and progression of neurological symptoms, orthopedic and neurological disorders should be a cause for MRI studies in order to find hidden spinal dysraphisma.

The purpose of the study. Determine the clinical significance and frequency of major clinical and instrumental signs of various types of latent spinal dysraphism in congenital myelopathy in children.

Material and methods. The work is based on an analysis of diagnosis and treatment of 144 children (67 (46.60\%) boys and $77(53.40 \%)$ girls) aged from one day to 15 years with osteoneural myelopathy observed in "the department planned surgery GKDB" No 2 of Tashkent city; in "the pediatric ward RSCN MoH of Uzbekistan"; in "the pediatric neurology clinic TashPMI" for 2008 - 2013 г. Distribution of patients by age was as follows: children up to 1 month accounted for $26(18 \%)$, up to 12 months - $69(48 \%)$, from 1 up to 3 years - $24(16.6 \%)$, from 4 to 6 years - $13(9 \%)$, from 7 to 15 years $12(8.3 \%)$ patients.

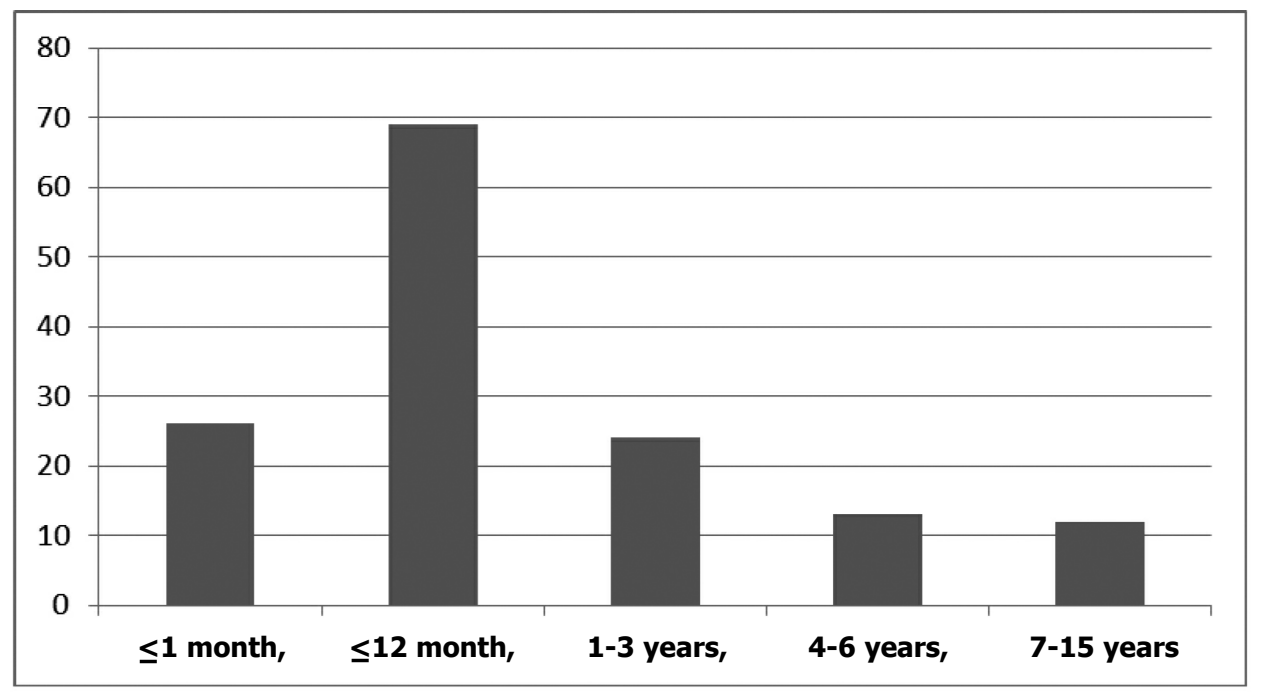

Fig.2. Distribution of patients by age

The examination included clinical and neurological research, clinical and biochemical analyzes of blood and urine. Patients also performed a computer-tomography (CT) or MRI of the spine and spinal cord, and ultrasound neurosonography internal organs. To determine the nature of disorders of defecation and urination held special urological research and proctology.

Results and discussion. Dysraphism of spine and spinal cord in our study were presented in the form of: 1) spina bifida cystica - 109 (76\%): a) meningocele - $27(25 \%)$; b) meningoradikulotsele 
- 33 (30\%); c) myelomeningocele - 38 (35\%); d) mielotsistotsele $-8(7.3 \%)$; e) rahiskhizis-3 $(2.7 \%)$;

2) spina bifida complicata - $3(2 \%)$;

3) spina bifida occulta - $32(22 \%)$.

Hidden spinal dysraphism (HSD) (71 patients) - is a diverse and heterogeneous group of malformations of the spine and spinal cord, in which there was no violation of the integrity of the skin above defect vertebrae were presented in the form of fixed spinal cord syndrome - 17 (24\%), spinal lipoma - 3 $(4.2 \%)$, the dorsal dermis sinus - $6(8.4 \%)$, diastematomyelia - $5(7 \%)$, gidromielii - $3(4.2 \%)$, syringomyelia - $5(7 \%)$, splitting edges vertebrae $-32(45 \%)$. In $9(12.7 \%)$ patients showed the simultaneous combination of two or more kinds.

HSD at - $37(52.1 \%)$ patients, as observed anomalies associated with spinal hernias; in 34 $(47.8 \%)$ cases as an independent state. Individual options (fixed spinal cord hidromielia, syringomyelia, vertebral defects) HSD are interpreted:

a) primary, not associated with operations and were detected by CT and MRI studies performed before surgery $44(62 \%)$;

b) secondary similar violations do not occur in complex preoperative evaluation of patients and appeared after excision of spinal hernias 17 $(24 \%)$

c) In $10(14 \%)$ patients with HSD origin remains unknown, since in these cases prior to surgery CT and MRI studies haven't been conducted.

The most common form of hidden spinal dysraphism is splitting arches of the vertebrae (spina bifida occulta), found in our observations in 32 $(45.0 \%)$ patients. The high frequency of this type of hidden spinal dysraphism because this pathology in $24(75.0 \%)$ patients were found during the examination of children with urological diseases and proctologic. Pathology manifested in the form of one vertebra cleft arc - in $15(47.0 \%)$, cleft arc several vertebrae - in $16(50.0 \%)$, cleft arc all vertebrae - in $1(3.0 \%)$.

Neurological symptoms depend on the age of patients, usually related to the nature and severity of myelodysplastic syndrome fixed spinal cord and spinal cord tension. Of the 32 patients with spina bifida occulta in $5(16 \%)$ children of neurological disorders were observed. 27 (84\%) children had neurological symptoms in the form of disorders of the pelvic-type incontinence - in $22(69 \%)$ children, and that was the main reason for seeking parents to specialists; not gross motor disorders in $14(44 \%)$ patients, to which parents of patients didn't complain, and they were identified by careful neurological examination. Movement disorders were as hypotonia - in $9(64 \%)$, reduced muscle strength and latent paresis of the lower limbs - in $5(36 \%)$ patients. Numbness in these patients was the segmental type and hypoesthesia - $11(34 \%)$ patients revealed precisely in dermatomed who had innervation roots extending from the level of the split arches of the vertebrae. An objective examination in $24(78 \%)$ patients in the split region arches of the vertebrae marked symptom of the Faun - the presence of one or more signs of skin: Inverted and skin atrophy or swelling of tissues, scars, pigmentation, hypertrichosis. In $3(9 \%)$ patients had pain along the spine and lower extremities, and $1(3 \%)$ patients - a sense of the type of the electric current along the spine when tapped on the spinous process adjacent abnormal vertebra - Lhermitte syndrome.

One of the adverse events in HSD are pelvic disorders. These disturbances were observed in $62 \%$ of patients with spina bifida occulta as defecation disorders, urination or in combination of this pathology.

When combined with HSD spinal hernias in $25(60 \%)$ patients had other types of HSD - 14 $(33 \%)$ and spina bifida complicata in - $3(7 \%)$ patients had severe neurological symptoms, as demonstrated by the absence or restriction of movements, disorder is more sensitivity in the lower extremities and perineum, trophic disorders and pelvic function as hypereflexive type urination and incontinence.

Conclusions 1. Clinical-neurological picture hidden spinal dysraphism of primary or secondary origin based on objective manifestations of dysraphism of particular form and is a progressive increase in phenomena urinary and faecal incontinence, exacerbating paresis of the lower 
limbs, impaired sensation in the crotch area, and in some cases the development of trophic disorders of the same localization. Presence and severity of disorders of the pelvic organs define high disability and complicate the social adaptation of patients.

2. High HSD combination with urogenital and anorectal anomalies contribute to aggravation of their flow and adversely affect the functional results of operations performed and

\section{REFERENCES}

1. Akhmediev Sh.R., Akhmediev M.M. "Fixed brain syndrome in children with spinal dysraphism"/Achievements, problems and prospects of the health of children and adolescents: Materials Republican scientific-practical conference, Tashkent, 2010.-P.27-29.

2. Braev A. T., Erohin A.P., Nikolaev V. "Diagnosis and treatment of urological complications, and approaches to the treatment of children with myelodysplasia"/"The Present and Future of Pediatric Surgery." Moscow conference materials. - 2001 P.40.

3. Voronov V.G. "Congenital malformations of the spinal cord and spine in children". St. Petersburg. - 1998. - P. 53. 4. M. Orlov "Syndrome of "stretched spinal cord" with lipomeningotsele in children". Kiev: Institute of requires specific treatment and residual functional disorders.

3. Early diagnosis of HSD depends on alertness paediatricians and neurologists to this pathology. As whether the child skin stigmata in the lumbosacral region, the appearance and progression of neurological symptoms, orthopedic disorders should be an occasion for a thorough investigation. For the diagnosis of various forms of spinal dysraphism leading method is CT and MRI.

Neurosurgery named after Academician A.P. Romodanova AMS 2002.

5. Shomansurov Sh.Sh., Ohunboeva D.A., Rizaeva N.T., "Clinical-neurological and computer-tomographic parameters in patients with enuresis on the background of the minimum spinal failure". Neurology - 2005, № 4C.2-3.

6. Yugay I.A., Ahmediev M.M., Mahmudov Sh.D. "Possibility of magnetic resonance imaging in spinal dysraphism diseases"/VIII Scientific Conference radiologists Uzbekistan. Tashkent - 2010.-S.322-323.

7. Caldarelli M. Di Rocco C. La Marca F. Treatment of hydromyelia in spina bifida//Surg. Neurol. 1998. - V.50 (5). - P. $411-420$

\title{
PEЗЮМЕ
}

\section{СКРЫТЫЙ СПИНАЛЬНЫЙ ДИЗРАФИЗМ В СТРУКТУРЕ ОСТЕОНЕВРАЛЬНЫХ АНОМАЛИЙ ПОЗВОНОЧНИКА У ДЕТЕЙ}

\author{
Маджидова Я.Н., Эргашева Н.Н., Эргашева Н.Н. \\ Ташкентский Педиатрический Медицинский Институт, Ташкент, Узбекистан
}

\begin{abstract}
Несмотря на многолетнее изучение проблемы спинального дизрафизма, актуальность ее связана с высокой частотой рождения детей с этой патологией и отдаленными последствиями, имеющими медико-социальное значение. На верифицированном материале 144 больных детей с остеоневральными миелопатиями проанализированы частота и характеристики имеющихся неврологических расстройств при скрытом спинальном дизрафизме. Установлено, что высокое сочетание скрытого спинального дизрафизма с урогенитальными и аноректальными аномалиями способствуют сугублению их течения.
\end{abstract}

Ключевые слова: спинального дизрафизм, остеоневральные миелопатии, дети. 
XÜLASə

\section{UŞAQLARDA ONURĞANIN OSTEONEVRAL ANOMALIYALARI STRUKTURUNDA GIZLI SPINAL DIZRAFIZM}

\section{Məcidəva Y.N., Erqaşeva N.N., Erqaşeva N.N.}

Daşkənd pediatrik tibb institutu, Daşkənd, Özbəkistan

Spinal dizrafizm probleminin uzun illərdir ki, tədqiq olunmasına baxmayaraq, bu patologiyalı uşaqların doğulmasının yüksək tezlikdə olması və tibbi-sosial əhəmiyyətə malik uzaq nəticələrinə görə hələ də aktualdır. Osteonevral mielopatiyalı 144 xəstə uşağın verifikasiya olunmuş materialları əsasında gizli spinal dizrafizm zamanı rast gəlinən nevroloji pozulmaların tezliyi və xarakteristikaları tədqiq edilmişdir. Təyin edilmişdir ki, gizli spinal dizrafizmin urogenital və anorektal anomaliyalarla yüksək müştərəkliyi onların gedişinin pisləşməsinə səbəb olur.

Açar sözlər: spinal dizrafizm, osteonevral mielopatiya, uşaqlar.

Redaksiyaya daxil olub: 10.02.2014

Çapa tövsiya olunub: 04.03.2014

Rayçi: t.e.d., dos. R.Hasənov 